педагогічна діяльність Миколи Неплюєва / Н. О. Ковальова // Матеріали IX Всеукраїнської історико-краєзнавчої конференції 3 міжнародною участю (24-25 листопада 2011 р.). - Суми: Вид-во СумДПУ ім. А. С. Макаренка, 2011. - С. 278-282.

УДК 37.091 .4

Олеся Тесцова

\title{
ГЕРБЕРТ СПЕНСЕР - ОСНОВОПОЛОЖНИК РЕФОРМАТОРСЬКОЇ ПЕДАГОГІКИ
}

Тесцова О. О. Герберт Спенсер - основоположник реформаторської педагогіки.

Стаття висвітлює характерну рису видатного англійського філософа і науковця Герберта Спенсера як одного з ідейних основоположників реформаторської педагогіки. Зокрема, розглядається місце принципу свободи у його виховній системі; розкривається питання дисципліни задля усунення штучних покарань, особливу увагу звернено на виховний потенціал родинної системи виховання.

Ключові слова: Г. Спенсер, виховна система, інновації у виховній системі, принципи свободи у вихованні, шкільний предмет у виховній системі.

Тесцова А. А. Герберт Спенсер - основоположник реформаторской педагогики.

Статья расскрывает характерную особенность известного английского философа и ученого Герберта Спенсера как одного из идейных основоположников реформаторской педагогики. В частности, рассматривается место принципа свободы в его воспитательной системе; раскрывается вопрос дисциплины для предупреждения нецелесообразных наказаний, особенное внимание обращено на воспитательный потенциал семейной системы воспитания.

Ключевые слова: Г. Спенсер, воспитательная система, инновации в воспитательной системе, принципы свободы в воспитании, школьный предмет в воспитательной системе.

Testsova A. A. Herbert Spencer - founder reform pedagogy.

Article revealing a characteristic feature of the famous English scientist and philosopher Herbert Spencer, as one of the ideological founders of progressive educational. In particular, the position of the principle of freedom in its educational system.

Key words: G. Spencer, the educational system, the principles of freedom in education.

Герберт Спенсер (1820-1903pp.) - один із найбільших інтелектуалів Англії. Д. Фіске бачив у ньому людину рівня Аристотеля й Ньютона, вважаючи, що його твори за широтою задуму перевершують праці цих двох філософів. Г. Джордж писав: «Величезна кількість людей визнає його за найбільш глибокого, оригінального й авторитетного мислителя 3 усіх сучасних нам, з усіх, які жили в XIX ст. і навіть 3 усіх, яких будь-коли бачив світ» [1, c. 1]. Поряд із ним Г. Джордж називав таких поважних науковців, як Д.С. Мілль, Р. Ланкастер, Р. Проктор, Г.Г. Льюіс, Д. Массон, Мек-Кош, Сент-ДжорджМіварт, Тіндаль, Гекслі, Ч. Дарвін, С. Джевонс, Г. Барнард [1, с. 2-3]. Л. Льар називав Г. Спенсера серед найвизначніших англійських реформаторів логіки [2, с. 33].

Відомий російський публіцист І. Шкловський [4, с. 483] у книзі «Англійські силуети» присвятив Г. Спенсеру окрему главу [3, с. 421]. К. Ушинський називав його «видатним мислителем» [5, с. 281], А. Лунк писав, що праці Г. Спенсера охоплюють усе, що було відомо до нього і водночас $є$ вихідним пунктом для безмежних подальших досліджень [3, с. 428]. 
Мета нашої розвідки - наукові погляди Г. Спенсера на розвиток реформаторської педагогіки. Він розробив свою виховну систему, головною рисою якої є гуманізм. При виборі навчальних предметів для нього найважливішим були інтереси дитини, він мав свою систему виховання.

Г. Спенсер значно посилив вимогу утилітарної спрямованості шкільних знань. Він не міг погодитися, що «майже завжди віддають перевагу знанням, якими можна похизуватись, а не таким, що є позитивними» [6, с. 2]. Узагальнив ситуацію він так: «Ми беремо до уваги не ті знання, якими маємо дорожити найбільше, а ті, якими можемо найлегше похизуватися, викликати подив, досягти почестей, високого становища в суспільстві й впливу» [6, с. 5].

Г. Спенсер, як і педагоги-реформатори, надавав великого значення естетичному вихованню, хоча й пов'язував його $з$ приємними заняттями й розвагами, з заповненням вільного часу. Він уважав, що «без живопису, скульптури, музики, поезії й приємних відчуттів, які називають красою всякого виду, життя втратило б половину своїх принад» [6, с. 44]. Як людина справи, надавав «перевагу знанням, які безпосередньо або опосередковано впливають на життєдіяльність і благополуччя людини, на щоденні наші обов' язки» [6, с. 45].

У XIX ст. масова школа робила акцент на гуманітарному складнику освіти, вивченні стародавніх мов, класичної літератури, історії та ін. Г. Спенсер, у противагу традиції, обгрунтовував i наголошував на необхідності якомога ширшого запровадження науковості освіти, на корисності наукових знань. Він писав: «Вивчення науки в найширшому іiі значенні $\epsilon$ найкращим керівництвом для всіх видів діяльності» [6, с. 62]. Таке зміщення акценту відповідало не лише утилітарному принципу, але й вимогам до реформування самих методів навчання. Перенесення методів науки в школу мало суттєвий виховний ефект, дозволило розвивати в учнів упевненість у своїх силах, самостійність, ініціативу, послідовність, правдивість, чесність, жертовність. Г. Спенсер вважав: «Для людства завжди було, є й буде необхідним для регулювання своїх дій вивчати науку фізичного, розумового й соціального життя й визнавати, що наука життя $\epsilon$ ключем до всіх останніх наук» [6, с. 63].

Розглядаючи методику розумового виховання, Г. Спенсер запропонував нову систему навчання, головним постулатом якої був принцип природо відповідності Й. Песталоцці, ідея природовідповідного розвитку й формування задатків і сил людського роду. Цей принцип в інтерпретації Г. Спенсера звучить так: «Порядок і метод виховання дітей мають неухильно узгоджуватися 3 природнім процесом розумового розвитку»; «у справі виховання успіх може бути досягнутий тоді, коли ми підпорядковуємо свої дії спонтанному розвитку, через який проходить розум кожної людської істоти на шляху до зрілості»; «основний принцип навчання полягає в тому, щоб порядок розподілу предметів і методів відповідав порядку розвитку й ступеню діяльності дитячих здібностей» [6, с. 76-77].

Виходячи зі своїх філософських і педагогічних поглядів, висновків тогочасної психології, узагальнивши теоретичний матеріал, Г. Спенсер розробив основні принципи нової дидактики, в основі яких «сім законів розумового розвитку дітей і які цілком узгоджувалися 3 принципом природо відповідності Й. Песталоцці, конкретизували напрямки його застосування в навчальному процесі і спиралися на останні досягнення психології» $[11$, с. 256].

Система, запропонована Г. Спенсером, здатна здолати прірву, яка досить часто існувала між учителями й учнями в старій школі. Адже «та особистість, яка постійно допомагає дітям в їх прагненнях до мети, часто доставляє їм випадки насолоджуватися 
розумовими перемогами, щоденно заохочує їх до праці і радіє їх успіхам,- така особистість викликає в дітях щиру приязнь до себе, а якщо вона буде послідовною у своїх діях, то діти гаряче до неї привернуться» [6, с. 122].

Г. Спенсер теоретично передбачив i обгрунтував прихід реформаторської педагогіки, іiі основні принципи. Він виходив з того, що існує прямий зв'язок між умовами громадського життя й системами виховання, які $є$ проекціями існуючих у певний час суспільних відносин, що зміни в одній системі викликають аналогічні зміни в іншій.

У книзі «Виховання розумове, моральне й фізичне» Г. Спенсер убачав перехідним в педагогіці те, що стара система виховання вже себе скомпрометувала й вичерпала, хоча залишалася ще досить сильною і панівною, а нова народжувалась. Оскільки нових методів виховання лише дошукувалися, то, на думку філософа, певне розмноження систем освіти, розкол у питаннях виховання без сумнівів має дати гарні результати, адже кожен з реформаторів педагогіки, «сповідуючи яку-небудь нову ідею, яка більшменш спирається на факти, горить бажанням довести правильність свого плану, наполегливо трудиться над розробкою окремих частин його, нічого не шкодує, щоб голосніше оголосити свій успіх і при цьому, звичайно, безжально критикує своїх конкурентів. Спрямовані до однієї і тієї ж мети зусилля мають поступово привести до істини» [6, с. 68-69].

Для Г. Спенсера важливим було те, що всі громадські інститути, всі суспільні відносини мають один спільний корінь, тому «зміни, якими вносяться перетворення до однієї галузі, перебудовують усе» [7, с. 206]. Водночас науковець бачив і певну неузгодженість, відставання одних змін від інших, коли політичні зміни відбувалися досить швидкими темпами, а за зміни в системі освіти й виховання доводилося боротися, доводити їх необхідність, актуальність, потрібність не лише владі, але й суспільству, оскільки старі традиції залишалися досить сильними й живучими. Однією 3 невід'ємних складових реформаторської педагогіки була критика недоліків традиційної школи та ї̈ методів виховання. Пропонуючи свої принципи й систему виховання, Г. Спенсер постійно порівнював їх $з$ традиційною системою, наголошуючи на її грубості й неспроможності, гостро ії критикуючи. Він критично оцінював примусове виховання як із загальнофілософських i етичних принципів концептуально, так i 3 позиції конкретних наслідків застосування хибної усталеної виховної системи на практиці.

Загальні аргументи Г. Спенсера проти примусового виховання такі: новітні виховні системи все більше відмовляються від методів примусового виховання; «застосування грубої сили для завдань виховання містить у собі радикальне зло» [7, с. 206]; результати примусового виховання несумісні з засобами, якими вони отримані; «примус може явно породити лише зовнішні прояви»; «примус може лише обмежити,- він не в змозі виховати»; «суворістю можна породжувати лише лицемірів- це крайня межа іiі успіхів» [7, с. 209]. У критиці старої школи Г. Спенсер послідовний і принциповий іiі опонент. Він викриває не окремі їі вади, не другорядні недоліки, а доводить хибність самих її основ, самих підвалин.

Недоліком традиційної системи виховання філософ уважав те, що вона не спиралася на досягнення психології. У цьому Г. Спенсер дуже співзвучний із тим, що пізніше декларуватимуть педагоги-реформатори. Він писав: «Яка величезна різниця між існуючим методом викладання й тим, який мав би бути, коли майже ніхто з батьків і дуже багато з наставників незнайомі з психологією. Розроблена система навчання дітей помилкова і за своїм змістом, і за прийомами; корисний розряд знань усунутий, а непотрібний нав'язується силоміць до того ж хибним шляхом i хибним порядком» $[6$, с. $34-35]$. 
Розробляючи теорію морального виховання, Г. Спенсер підходив до проблеми відповідно до своїх філософських принципів. Основоположним постулатом його соціальної теорії був закон про рівну свободу, який стверджував: «Закон справедливих соціальних відносин полягає в тому, що кожна людина вільна робити все, що вона хоче, якщо вона не порушує рівної свободи іншої людини» [7, с. 121].

Оголошуючи закон про рівну свободу основним, Г. Спенсер не робив винятків, поширюючи його дію і на дітей, вбачаючи, що він «має однаково застосовуватись і до неповнолітніх, і до дорослих, що «дитина може вимагати для себе свободи» [7, с. 198], що «права дітей такі ж великі, як і права дорослих; застосування примусу щодо дітей порушує їх права і тому містить у собі несправедливість» [7, с. 203]. Всебічно проаналізувавши дану проекцію, філософ зробив висновок: «Отже, ми можемо сказати відносно поширення закону про рівну свободу на дітей, що він диктується природною справедливістю й виявляється корисним на основі утилітарних міркувань» [7, с. 218].

На думку Г. Спенсера, «дитину слід привчати до тих зусиль тіла й душі, які будуть необхідні для неї в подальшому житті», і «виховання має на увазі або цю мету, або нічого» [7, с. 211]. Здібністю, яка буде найпотрібнішою дитині в дорослому житті, педагог уважав уміння керувати собою. Цей розвиток $є$ метою і засобом морального виховання. Г. Спенсер писав: «Моральне виховання прагне до того, щоб зменшити схильність людини захоплюватися першим враженням, привчати іiї до самовладання, до рішень, які прийняті за участю всіх почуттів, які зріло обдумані й холоднокровно ухвалені. Той, хто хоче керувати своїми пристрастями в зрілому віці, має привчатися керувати ними протягом своєї молодості» [7, с. 212]. Подібна методика виключала насильницьке виховання, вона могла виступати лише складовою вільного виховання.

Послідовне використання у вихованні принципу природних реакцій, на думку педагога, має ряд переваг. Дитина не завжди задумується про наслідки своїх дій. Використання цього принципу акцентує ії увагу саме на природних логічних наслідках iï вчинків, змушує відчувати ці наслідки, вчить іï розпізнавати суттєву різницю між гарною і поганою поведінкою.

На відміну від штучних покарань, система природних реакцій встановлює значно очевидніший і природніший причинно-наслідковий зв'язок між дією і реакцією, тому, на думку Г. Спенсера, така природна дисципліна $\epsilon$ цілком справедливою дисципліною. Ця система не дозволяє виникати антагонізму між батьками й дітьми, зумовленому застосуванню штучних покарань. Адже суб'єкт природної реакції не персоніфікується, ним постає сама природа. Науковець писав: «Система дисципліни, при сприянні природних реакцій, набагато менше шкодить характеру дітей, так як вони самі усвідомлюють іiі безумовну справедливість і так як вона, значною мірою, замінює особисте втручання батьків безликим посередництвом природи» [6, с. 149]. У результаті стосунки між вихователями й дітьми стають дружніми, що сприяє благотворному моральному впливу на вихованців.

Г. Спенсер наголошував, що виховуючи слід більше використовувати почуття, емоційний складник, що «виховання може здійснити моральний вплив тільки тоді, коли буде діяти більше на почуття, ніж на розум»; що «важливіше не стільки дати зрозуміти, що таке добре і що таке погано, скільки дати це відчути; навчити любити добро й ненавидіти зло; пробуджувати шляхетні бажання й викорінювати погані; привести душу дитини в такий стан, коли справедливість буде для неї природним та інстинктивним способом дії» [7, с. 399].

Говорячи про розумове й моральне виховання, пов'язуючи це зі змаганням, конкуренцією націй, він не міг обійти увагою питання фізичного розвитку, оскільки вважав «значною мірою необхідним виховувати наших дітей так, щоб не тільки 
розумово підготувати їх до майбутньої боротьби, але й фізично зробити їх здатними до перенесення різних негараздів» [6, с. 174].

Г. Спенсер рішуче виступав проти розумового перевантаження дітей, яке пов'язував зі значним збільшенням обсягу навчального матеріалу; доводив, що подібне перевантаження веде до розладу здоров'я. Педагог наголошував: «Існує відомий порядок і відома поступовість розвитку; якщо виховання дітей йде відповідно до цього порядку і з цією поступовістю, то результати будуть чудовими» $[6,214]$. Розумове перевантаження заважає якісному засвоєнню навчального матеріалу, породжує відразу до навчання, книги, не залишає часу на самоосвіту», тому закликав «однаково дорожити тілом і розумом» $[6$, с. 226].

Ідеї Г. Спенсера мали величезний вплив на педагогів-реформаторів кінця XIXпочатку XX ст., були ними творчо використані й розвинуті, тому науковця справедливо вважають одним із фундаторів реформаторської педагогіки.

\section{Література}

1. Генри Дж. Запутавшийся философ/ Джордж Генри. - СПб. : Изд. Л. Ф. Пантелеева, 1902. - 335 с. 2. Льар Л. Английские реформаторы логики в ХІХ в. / Луи Льар.- СПб. : Тип. Х. Брауде, 1897.- 201 с. 3. Дионео. Английские силуэты / Дионео.- СПб.: Тип. Н. Н. Клобукова, 1905. - 502 с. 4. Дионео // Большая советская энциклопедия / Гл. ред. О. Ю. Шмидт. - Т. 22. - М. : ОГИЗ РСФСР, 1935. - С. 483. 5. Ушинський К. Д. Людина як предмет виховання. Спроба педагогічної антропології / Костянтин Ушинський // Вибрані педагогічні твори: У 2 т. - Т. 1. - К. : Рад. школа, С. 192-471. 6. Спенсер Г. Воспитание умственное, нравственное и физическое / Герберт Спенсер. - СПб. : Родник, 1883. - 228 с. 7. Спенсер Г. Изложение социальных законов, обусловливающих счастье человека / Герберт Спенсер. - СПб. : Изд. В. Врублевского, 1906. - 536 с. 8. Спенсер Г. Основания науки о нравственности / Герберт Спенсер. СПб. : Изд. И. И. Билибина, 1880. - 361 с. 9. Спенсер Г. Опыты научные, политические и философские / Герберт Спенсер. - Ч. І. - СПб. : Изд. А.О. «Издатель», 1899. - 270 с. 10. Спенсер Г. Основания этики / Герберт Спенсер. - Т. І. - Ч. 1. - СПб. : Изд. А. О. «Издатель», 1899. - 209 с.

\section{РЕАЛІЗАЩІЯ ГЕНДЕРНОЇ ОСВІТИ БАКАЛАВРІВ ГУМАНІТАРНИХ СПЕЦАЛЬНОСТЕЙ У ВИЩИХ НАВЧАЛЬНИХ ЗАКЛАДАХ КАНАДИ}

Юр’єва О. Ю. Реалізація гендерної освіти бакалаврів гуманітарних спеціальностей у вищих навчальних закладах Канади.

У статті проаналізовано основні елементи процесу реалізації гендерної освіти бакалаврів гуманітарних спеціальностей у вищих навчальних закладах Канади. На основі аналізу навчальних програм гуманітарних факультетів 42 університетів Канади визначено ключові етапи та компоненти реалізації гендерної освіти. У результаті осмислення ролі гендерної освіти в підготовці бакалаврів гуманітарних спеціальностей університетів Канади розроблено структурно-логічну схему цього процесу.

Ключові слова: гендер, гендерна освіта, компоненти навчального процесу, бакалаври гуманітарних спеціальностей. 